\title{
Two Jewish studies related postdoctoral projects in Scandinavia
}

Aвstract - Below, Wally V. Cirafesi of University of Oslo and Katharina E. Keim of Lund University briefly present their postdoctoral projects within the area of Jewish Studies. Cirafesi has just completed his dissertation on the Gospel of John within its first-century Jewish environment, entitled 'John within Judaism: Religion, Ethnicity, and the Shaping of Jesus-oriented Jewishness in the Fourth Gospel', and has received a postdoctoral fellowship at the Norwegian School of Theology, Religion, and Society (Menighetsfakulteten). Keim completed her dissertation on a work of Jewish bible interpretation at the University of Manchester in 201 4, published since as Pirqei deRabbi Eliezer: Structure, Coherence, Intertextuality (Brill, 20I6). She has recently begun a postdoctoral fellowship in Jewish studies at Lund University. Both projects are interdisciplinary and concern interaction between Jews and Christians in Antiquity, and in Keim's case also interaction with Islam.

\section{Wally V. Cirafesi, University of Oslo}

\section{Building Jewish and Christian identity} in the village of Nahum: a social and cultural history of Jews and Christians in Capernaum from the first to the sixth century $\mathrm{CE}$

In 1838 , the American excavator Edward Robinson discovered the remains of what turned out to be a large white limestone synagogue from Late Antique Capernaum, boldly describing the remains as some of the most remarkable ever found in Palestine. Capernaum is a small village known from New Testament sources as the home of the apostle Peter and an important place for Jesus's preaching and miracle-working. It is also known from later rabbinic literature as the home of certain Jewish 'heretics'. Since the I970s, however, it has been a major archaeological attraction, located on the north-western coast of the Kinneret Lake and touted by the Franciscan Custodia Terrae Sanctae as the 'town of Jesus'. Since the nineteenth century, then, this little village has been of significant interest to New Testament historians as well as scholars of Second Temple Judaism and Late Antique Palestine.
While the great white synagogue was itself a magisterial discovery, presenting a rich array of interpretative challenges to synagogue scholars concerning its history, architecture and institutional function, what makes Capernaum a unique site is that just twenty-five meters to the south of the synagogue were discovered the remains of a Byzantine church constructed in the shape of three concentric octagons, erected in the fifth century ostensibly to commemorate the site of St Peter's house. There is no doubt, then, that by the time of the fifth century, Jews and non-Jewish Christians interacted on daily basis, even if only through the imposing visuality of their respective buildings. The question this raises is: how did Jewish-Christian relations in Capernaum arrive at this fifth-century situation? That is, how did Capernaum evolve from an apparently small Jewish village during the time of the historical Jesus into a multi-cultural pilgrimage site for Byzantine Christians?

'Building Jewish and Christian Identity in the Village of Nahum' is a project that seeks to answer these questions and to understand the social and cultural history of how 'Judaism' and 'Christianity' emerged in Capernaum as distinct 
religions that nevertheless mutually influenced each other. The project will examine the literary sources and the archaeology of the village, especially the architectural histories of the limestone synagogue and octagonal church, and ask what they might tell us about the construction of Jewish and Christian identity there from the time of Jesus to the Piacenza Pilgrim. It will also attempt to understand Jewish-Christian interaction at Capernaum within the context of other nearby sites in Galilee, which developed contemporaneously with the village. The hope is that such a historical study of Capernaum in its diachronic and regional contexts will shed significant light on the development of JewishChristian relations in Late Antiquity - in Palestine and beyond.

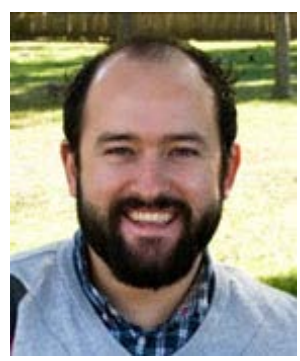

Wally V. Cirafesi is currently a doctoral research fellow in New Testament Studies in the Faculty of Theology at the University of Oslo. In January 2019, he begins a postdoctoral research fellowship at the Norwegian School of Theology, Religion, and Society, Oslo.
Katharina E. Keim, Lund University

\section{The interchange of religious ideas}

between Judaism, Christianity, and Islam:

a comparative analysis of exegetical

responses to themes in Genesis 1-3

The early Islamic centuries were a major turning point in history. The Islamic conquests of the seventh century spread across Israel-Palestine and Mesopotamia, forcing the Christian Byzantine Empire back into Anatolia and bringing the Sasanian Empire to its end. Jewish and Christian communities settled in these areas were brought under the control of the expanding Islamic world, and faced the challenge of a major political, linguistic and religious upheaval. The new religion of Islam saw itself as following in the footsteps of both Christianity and Judaism. Its prophet Muhammad was the last of a long line of prophets of God, including Jesus and Moses, going all the way back to Abraham. Muhammad was the 'seal of the prophets', God's last prophetic word to humanity, whose revelation topped out the earlier revelations and showed their true meaning. The emergence of Islam thus challenged the established views of Judaism and Christianity, and religious boundaries became blurred. Islam not only demanded an individual response from adherents of the older faiths, but also reconfigured the existing relationships between them. Battle-lines were being constantly redrawn - before all three religions finally settled down in the entrenched positions in which they have largely remained to the present day.

This project will explore the exchange of religious ideas between these three faiths in this formative period. It will take as its focus exegetical developments relating to selected themes in Genesis $\mathrm{I}-3$ in three key texts dating to the seventh to tenth centuries, one from each tradition - Pirqei deRabbi Eliezer (Judaism), Cave of Treasures (Christianity) and the first book of al-Tabari's History of the Prophets and the Kings 
(Islam). The Genesis chapters are rich in theological themes, many of which were foci of dispute between the three faiths and are found in the discourses of the above-named works. These include: the pre-mundane creation, the place of the angels in the natural order, the creation of the world, cosmography, the early history of the world, the origins of evil, and the fall of humanity. The three core texts will be read intertextually against one another, as well as against a wider corpus of early Islamic literature and Jewish and Christian literature reaching back into the Second Temple Period and Late Antiquity. The intertextuality which this reading discloses will be set in its socio-historical context through an attempt to relate it to the social settings in which contact between members of the three faiths took place (business relationships, personal friendship, the coffee shop, the majlis, the book-market, etc.). Through this approach, the project aims to develop a more nuanced understanding of the kinds of interaction, exchange and engagement that took place in order to enrich our knowledge of the impact that the emergence of Islam had on the development of interreligious relations of the period.

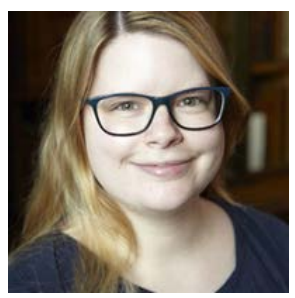

Dr Katharina E. Keim is postdoctoral fellow in Jewish Studies at the Centre for Theology and Religious Studies in Lund University, Sweden. 